\title{
腹腔鏡手術中のラテックスによるアナフィラキシーショックの1例
}

\author{
富山県立中央病院 産婦人科
}

飴谷由佳、舟本 寛、舌野 靖、谷村 悟

\section{A case of latex anaphylactic shock in a patient undergoing laparoscopic surgery}

\author{
Yuka Ametani, Hiroshi Funamoto, Yasushi Shitano, Satoshi Tanimura \\ Department of Obstetrics and Gynecology, Toyama Prefectural Central Hospital
}

\begin{abstract}
Latex can cause life-threatening allergic reactions in patients with a history of a rubber allergy. We describe a case of severe anaphylactic shock due to latex in a woman who was undergoing laparoscopic surgery.

A 33-year-old woman with a uterine leiomyoma was admitted for a total laparoscopic myomectomy. The operation was converted to a laparoscopic-assisted myomectomy (open-laparotomy) because there were severe adhesions around the uterus. During the surgical procedure, the patient experienced the sudden onset of oxygen desaturation, severe hypotension, and bradycardia. We interrupted the surgery and the patient was given $100 \%$ oxygen. The diagnosis of anaphylaxis was not evident during the early period of resuscitation. First, we suspected the cause of shock was a pulmonary gas embolism; we then ruled out other causes, such as cardiogenic shock and hemorrhagic shock. Therefore, we performed a transesophageal echocardiography and chest X-ray. We noticed that her face and chest were flushed. We made a diagnosis of anaphylactic shock and suspected that latex was the cause of anaphylaxis. We changed the urinary catheter, which was made from latex, for a silicone catheter. The patient was resuscitated successfully with manual ventilation, intravenous fluids, and medications. The patient had undergone two laparotomies uneventfully, and later we determined she had atopy.

To prevent anaphylactic shock during surgery, it is important to identify potential risk factors, such as atopy, adverse reactions to foods, and latex items. If latex allergy is confirmed or strongly suspected, patients should be managed in a latexfree environment.
\end{abstract}

キーワード : ラテックスアレルギー、腹腔鏡、アナフィラキシーショック

\section{はじめに}

手術中の合併症にはいろいろあり、中でもアナ フィラキシーショックは重篤で直ちに適切な治療 を行わないと救命困難となる恐れがあるが、一方 でその原因物質を取り除くことができれば速やか に回復する可能性がある。今回腹腔鏡手術中にシ ヨック状態に陥ったが、幸いラテックスによるア
ナフィラキシーショックを疑い治療することによ り救命できた症例を経験したので報告する。

\section{1 症例}

33歳の未婚女性、老人ホームで介護職。過去に 他院で卵巣腫瘍茎捻転に対する腹腔鏡手術と付属 器膿瘍に対する開腹手術の既往がある。今回は子 宮筋腫が増大してきたため全腹腔鏡下筋腫核出術 
を行う予定であった。術前検査では血液検査や胸 部X線写真、心電図などにおいて特に異常所見を みとめなかった。問診ではアトピーがあり、また イカに対するアレルギーが疑われていた。術前の リスクファクターは手術既往あり、肥満、喫煙と 考えられた（図 1 )。

\section{図 1}

症例概要

\section{3才未婚 未経娃 職業:老人ホームで介護職}

【身長 体重】 $160 \mathrm{~cm} 、 75.2 \mathrm{~kg} 、$ BMI 29.4

【既往歴】1993年 卵巣腫瘍茎捻転 他院で腹腔鏡下手術
1993年 付属器膿韵 他院で開腹手術

【現病歴】2001年子宮筋腫のため他院より紹介初診 2003年 月経困難症に対して低用量ピルの内服を開始 2004年7月より增大した子宮筋腫の手術目的にGnRHの投与を行う

【アレルギー】幼少時より アトピーをみとめた いかアレルギーの疑いがあった

喘息 $(-)$

薬棛アレルギー(ー)

手術のリスクは 腹部の手術既往2回、肥満、喫煙と考えられた

手術経過：2005年 2 月 4 日、麻酔前投薬としてミ ダゾラム（商品名ドルミカム）シロップを内服後 に手術室へ入室し、硬膜外麻酔カテーテルを挿入 した。プロポフォール（商品名ディプリバン）と ベクロニウム（商品名マスキュラックス）を投与 後10時55分気管内挿管を行った。膀胱留置カテー テル（ラテックス製）を留置し、腹部から陰部を ポビドンョード（商品名イソジン）で消毒した後 子宮マニュピレーターを扱入した。臍部よりクロ ーズド法により気腹し $10 \mathrm{~mm}$ の光学視管を抻入し た。術者は 3 人ともラテックス製手袋を着用して いた。腹腔内を観察すると子宮周囲の癒着が強い ため、術式を全腹腔鏡下子宮筋腫核出術から腹腔 鏡補助下子宮筋腫核出術へ変更することとし11時 30分頃に下腹部に小切開を加えた。切開創は前回 の手術痏痕部であり皮下の癒着が強く開腹に多少 時間を要した。

11時43分 術者が皮膚切開部より腹腔内に手を挿 入して子宮周囲の癒着を確認していたところ急に 気道内圧が上がったため、麻醉科医は捚管チュー ブ内の吸痰を行った。突然酸素飽和度が急激に下 降し心拍数は急速に30回/分に低下した。麻酔開始 時から血圧を 5 分ごとに自動測定していたがこの とき測定不能となり脈は触知不能であった。急変 に対してスタッフの応援要請のために手術室内に 一斉コールを行った。
11時45分 心拍数が20回/分となったため心臟マッ サージを開始し蘇生のためにエピネフリン（商品 名ボスミン)、副腎皮質ホルモン（商品名ソルメ ドロール）、塩酸イソプレナリン（商品名プロタ ノール）を投与した。このとき気道内圧が高くバ ッグによる換気が困難な状態であった。薬品投与 にもかかわらず心拍数 $50 \sim 90$ 回/分、血圧 50 ～ $60 \mathrm{mmHg}$ 、酸素飽和度60 $80 \%$ と不安定な状態が 続き、腹腔内の状態を確認するために術者が手を 腹腔内へ挿入するたびに酸素飽和度や血圧の低下 をみとめた。腹腔内に出血をみとめなかったため 手術を中止し11時50分に閉腹を開始したが、腹膜 を閉鎖する際にも酸素飽和度や血圧の低下をみと めた。

腹腔鏡手術中の急変でありその原因としてガス 塞栓を疑った。心電図、経食道心エコーや胸部X 線写真を実施したが右房内に空気を疑う所見や右 房負荷所見はなくガス塞栓は否定的であった。経 食道心エコーを急遽準備したがガス塞栓を疑う手 術では呼気終末 $\mathrm{CO}_{2}$ 分圧や前胸部超音波ドプラー などのモニターが低侵襲で有用である ${ }^{1)}$ 。心機能 が良好であることと経臸エコーで腹腔内、後腹膜 腔に出血を疑う所見がないことから心原性ショッ ク・出血性ショックも否定的であった。あらため て全身状態を観察すると手足に冷感がなく四肢末 梢の血管が拡張しており、また顔面、胸部に発 赤・浮腫をみとめ、何らかのアナフィラキシーが ショックの原因であると考えられた。突然ショッ クに陥るまでの間全身状態が安定していたこと、 ショックに陥る直前に新たに投与した薬剤がない ことからアナフィラキシーの原因としてラテック スを疑った。膀胱留置カテーテルをシリコン製品 に交換し中心静脈よりノルエピネフリン（商品名 ノルアドレナリン)、塩酸ドブタミン（商品名ド ブトレックス）の投与を開始した。徐々に全身状 態は改善し血圧 $80 \mathrm{mmHg}$ 、酸素飽和度 $87 \%$ となっ たので気管内挿管をしたまま集中治療室へ搬送し た。15時には痛み刺激に反応がみられるようにな り、18時には意識清明になった。あらためて本人 に問診を行うと介護の仕事の際に手袋で手がかゆ くなること、過去にゴム風船をふくらました時に 顔が腫れたことがあるとわかった。ショック時に 採血した検査結果が後に判明したが、ラテックス 特異的 $\operatorname{IgE}$ 渵高值であり臨床症状とあわせ考えラ テックスによるアナフィラキシーショックであっ たと結論した。患者は確定診断のための皮膚テス トなどは希望されず、今後はラテックス製品を使 
用しないように日常生活における指導などを行い 術後10日目に退院した。

\section{2 考察}

本症例は腹腔鏡手術中の急変でありショックの 原因としてガス塞栓、出血性ショック、心原性シ ヨックなどが考えられたが当初はアナフィラキシ ーショックという診断は困難であった。またこれ らの除外診断のためには、超音波やX線などの検 查機器の準備や循環器専門医の協力を必要とした。 アナフィラキシーショックの原因が薬品ではなく ラテックスであると疑うことにより原因を除去す ることができた。原因除去後は徐々に全身状態の 改善がみられこれがまた診断につながったといえ る。幸い発症した場所がスタッフの多い日中の手 術室であったため診断・治療が行えたが、ラテッ クス製の製品は多岐にわたり院内各所に置かれて あるためラテックスによるアナフィラキシーショ ックは夜間や病棟、外来でも発症する可能性が十 分考えられる。

当院では本症例を経験後、ディスポ製品の素材 を改めて確認し、手術室や物品管理センターでは ラテックスフリー製品を購入した。またコスト増 加となるために全製品をラテックスフリー製品に することはできないが症例に応じて使用できるよ うにラテックスフリーセットを準備した2)。

医療者の健康のためにはラテックスフリー手袋 の使用が望ましいがコストと使用感の観点から現 在のところラテックス製ノンパウダー手袋の使用 と、またコーンスターチパウダーによるアレルギ 一の報告も多いことから使用後の流水による手洗 いをすすめている3)。手術用手袋のパウダーは炎 症反応を引き起こし癒着や肉芽を形成する。また Beezholdらは手袋のパウダーとラテックス蛋白が 結合すると報告している。医療者はこの結合体を パウダー手袋を使用するたびに吸引するおそれが ある ${ }^{4)}$ 。

ノンパウダー製手袋についてはその使用感を好 まない、慣れないなどの理由から院内ではなかな か普及しなかったが、本症例を担当した手術部の 看護師・麻酔科医師・産婦人科医師らがパウダー 手袋の使用によるアレルギー発症の危険性を訴え 徐々に普及した。院内全体では2005年 $4-7$ 月の 4 ケ月間にラテックス製ノンパウダー手袋の購入 数は滅菌手袋全体15516双のうち3696双 $(23.8 \%)$ であったが、2006年同時期では全体15391双のう ち7703双 $(49.0 \%)$ と増加した（図 2$)$ 。
図2

\section{当院における \\ ラテックス製ノンパウダー手袋の購入数}

\begin{tabular}{|c|c|c|c|c|}
\hline & $\begin{array}{l}\text { ラテックスス掣 } \\
\text { パウダー手 }\end{array}$ & $\begin{array}{l}\text { ラテックスス製 } \\
\text { ハンパウ手液 }\end{array}$ & 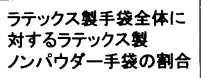 & $\begin{array}{l}\text { ラテックス } \\
\text { フリー手袋 }\end{array}$ \\
\hline $\begin{array}{l}\text { 2005年 } \\
\text { 4月〜7月 }\end{array}$ & 11820 & 3696 & $23.8 \%$ & \\
\hline $\begin{array}{l}\text { 2006年 } \\
4 \text { 月～7月 }\end{array}$ & 7703 & 7477 & $49.0 \%$ & 211 \\
\hline
\end{tabular}

院内全体では2005年4 7月にはラテックス製ハンパウダー手袋の使用数は ラテックス製手袋全体の $23.8 \%$ であったが、2006年同時期では $49.0 \%$ とっ ている。

新人や転入者への啓蒙のためには研修会などを 行うことも重要である。当院では今までに手術室 においてラテックスによるアナフィラキシーショ ックの経験がなかった。今回の経験からラテック スアレルギーについての意識を高め、またアレル ギー発症時に対応することができるように院内の 職員へラテックスアレルギーについての意識調査 を行いその後に院内研修会を開催した。研修会の 1 年後に滅菌手袋の使用頻度が高い手術室と産科 病棟の看護スタッフに再度意識調查を行った。

ラテックスアレルギーについて知っていると答 えたスタッフは初年度は全体の $41.5 \%$ 、1 年後は 手術室 $100 \%$ 、産科病棟 $72.0 \%$ と明らかに認知度が 高くなった（図 3 )。医療従事者がハイリスクで あることを知っていると答えたスタッフは初年度 $37.4 \% 、 1$ 年後は手術室 $94.0 \%$ 、産科病棟 $64.0 \%$ と 認知度が上がっていた（図 4 ）。ラテックスアレ ルギーの患者を担当したことがあると答えたス夕 ッフは初年度はわずか $6.0 \% 、 1$ 年後は手術室 $94.0 \%$ 、産科病棟 $53.0 \%$ であった（図 5 )。この中 にはラテックスアレルギーの疑い患者も含まれて いる。ラテックス製手袋の装着時に何らかの症状 を有しているスタッフは初年度 $23.5 \%$ 、1 年後は 手術室 $43.0 \%$ 、産科病棟13.0\%であった（図 6 ）。 Garyらは病院職員の $12.1 \%$ がラテックスの皮虐テ スト陽性であったと報告しており ${ }^{5)}$ また医療従事 者のおよそ3〜17\%がラテックスアレルギーという 報告もある6、7)。手袋使用時・使用後に気をつけ ていることとして、流水で洗う・ノンパウダー手 袋を使うと答えたスタッフが前年より増加してお り、ラテックスアレルギーについての意識が高ま った結果と考えられる（図 7 )。手荒れにより皮 膚の防御機能が低下するとラテックスに対する感 度が高くなるため手荒れの対策は大切である ${ }^{8)}$ 。 
図 3 当院職員へのラテックスアレルギー に対する意識調查-1
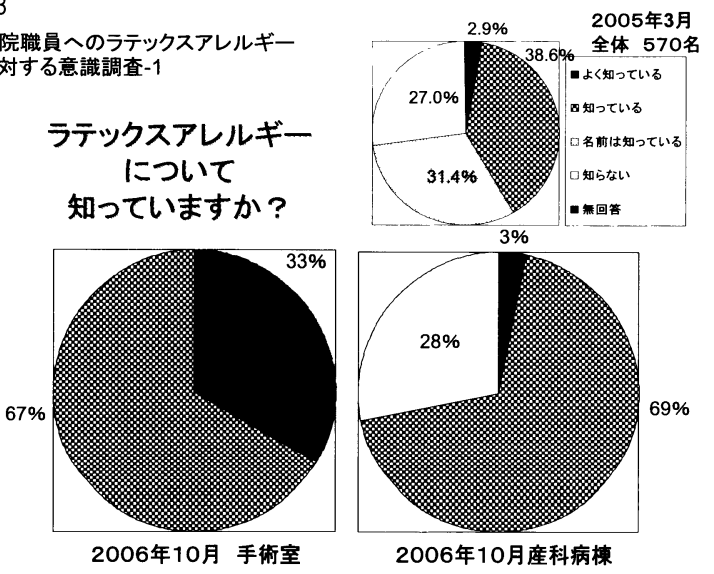

図 4

\section{当院職員へのラテックスアレルギー に対する意識調查-2 \\ 医療従事者が \\ ハイリスク群であることを \\ 知っていますか?}

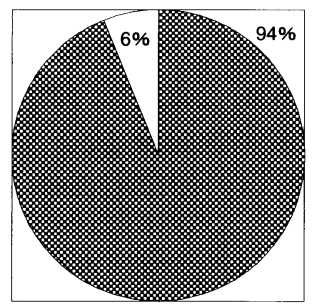

2006年10月手術室

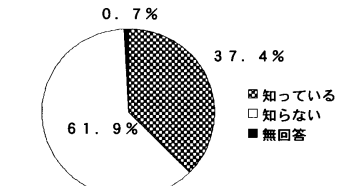

2005年3月 全体

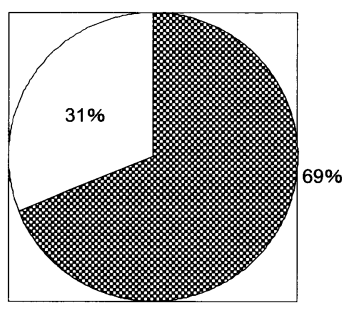

2006年10月 産科病植

図 5

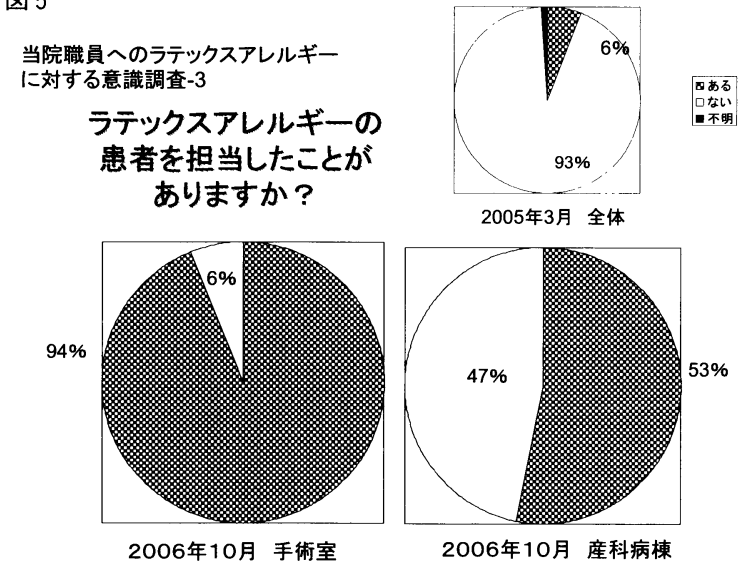

図 6

当院職員へのラテックスアレルギー に対する意識調査-4

ラテックス製手袋を装藉時に 何らかの症状が ありますか?

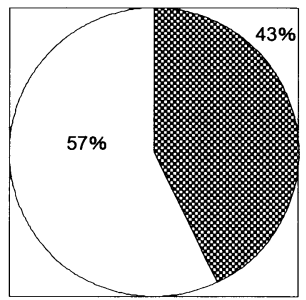

2006年10月手術室

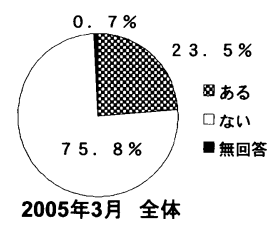

2005年3月 全体

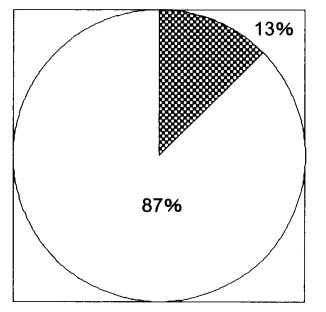

2006年10月 産科病棟

図 7

当院職員へのラテックスアレルギー
に対する意識調查-5

手袋使用時·使用後に 気をつけていることは

ありますか?

\begin{tabular}{|c|c|c|c|}
\hline & $\begin{array}{l}\text { 2005年 } \\
\text { 全体 }\end{array}$ & $\begin{array}{l}\text { 2006年 } \\
\text { 手術室 }\end{array}$ & $\begin{array}{c}\text { 2006年 } \\
\text { 産科病棟 }\end{array}$ \\
\hline 流水で洗う & $114(20)$ & 21 (63.6) & 29 (90.6) \\
\hline ハンパウダー手袋使用 & $42(7.4)$ & 21 (63.6) & 0 \\
\hline 皮鬳科受診歴あり & $24(4.2)$ & 3 & 0 \\
\hline ハンドクリーム使用 & $33(5.8)$ & 6 & 1 \\
\hline ステロイド使用 & 2 & 3 & 0 \\
\hline 気をつけていない & 5 & 2 & 3 \\
\hline
\end{tabular}

( )内は\%

本症例では術後の問診からラテックスアレルギ 一を疑わせる病歴を聞きだすことができたが、問 診時には常にアレルギーを念頭において聞くこと が重要である。フルーツに対する口腔アレルギー の患者はラテックス蛋白と交叉反応蛋白によるラ テックスアレルギーを起こすことが知られていて ラテックス・フルーツ症候群という ${ }^{9)}$ 。特にアレ ルギー素因のある場合（喘息やアトピーなど）、医 療従事者などではハイリスク群であることを認識 しなければいけない。本症例では患者は介護の仕 事で手袋の装着時に掻痒感を自覚していたが、患 者がそれをアレルギーであるとは考えていなかっ たため術前の「アレルギーはありませんか」とい う問診からラテックスアレルギーである可能性を 聞き出すことができなかった。果物による口唇な どの掻痒感やゴム使用時のかぶれなどラテック ス・フルーツ症候群を疑い具体的な言葉で聞き出 す努力が重要である。頻度の高い食物としてバナ ナ、アボガド、キウイ、クリ、トマト、ポテトが 有名でその他パパイヤ、パッションフルーツ、イ チジク、マンゴ、パイナップル、メロン、ピーチ、 ネクタリン、シラカバ花粉、リンゴ、ニンジンが 報告されている ${ }^{9)}$ 。本症例では今回が 3 回目の手 術でありラテックスに対して感受性が高まってい たと考えられる。ラテックス抗原そのものは水溶 性蛋白で汗やぬれた手、粘膜上皮などと接触し、 毛包などを通して吸収されることが知られている。 症状は吸収後数分で生じ、局所の蕁麻疹で始まり 全身の萇麻疹、ときにアナフィラキシー症状を呈 する ${ }^{10)}$ 。本症例では先に膀胱留置カテーテル（ラ テックス製）を挿入しているが、開腹操作に移っ て間もなくショックとなったこと、その後も腹腔 内の出血の有無を確かめるために術者が手を挿入 した時、閉腹時に全身状態が悪化したことから手 袋のラテックスが原因であったと推測される。 
当院では現在は術前や入院時の問診からアレル ギーが疑われた場合は電子カルテにその内容を記 載し院内の全スタッフが情報を共有できるように している。ラテックス・フルーツ症候群が疑われ る場合にはその確定診断が困難であるため、疑い 症例は全例ラテックスフリーセットを準備してい る。問診の工夫によりラテックスアレルギーの疑 い症例が増えておりショックを未然に予防できる ようになったと考えられるが、内診などの外来診 察時や検査時のアナフィラキシーショックの報告 が散見されることから ${ }^{11)} 、 今$ 後はさらに初診時の 問診での工夫が必要である。

本症例では患者が精查を望まなかったので実施 しなかったがラテックスアレルギーの診断方法に は臨床症状（痒み、紅斑、膨疹）と症状を誘発し たラテックス製品から抽出した溶液を用いた皮虐 テスト（プリックテスト、使用テスト）などがあ る ${ }^{12)}$ 。しかし皮虐テストによりアナフィラキシー が誘発されることがあり慎重に行うことが必要で ある。

ラテックスアレルギーの治療方法は、ラテック スアレルギーを疑った場合にはまず原因となる物 との接触をすみやかに絶つことである。その次に 生じた即時型反応に対して治療を行う。本症例の ようにアナフィラキシーショックを起こした場合 には気道の確保、エピネフィリンの投与（皮下注、 筋注)、静脈ルートの確保、輸液の急速投与、工 ピネフィリン投与後も気道狭窄症状が見られる場 合は $\beta 2$ 刺激薬、アミノフィリンの点滴静脈注射も すすめられている。また急性期の症状が治まった あとにも再燃することがあり注意を要する ${ }^{13)}$ 。

ラテックスアレルギーはそれを疑うことができ れば未然に防ぐことが可能である。アレルギーを 念頭においた充分な問診が重要であり疑わしいと きは躊躇なく可能な限りラテックスフリーの環境 で処置を行うことがよいと考えられる。

本文の要旨は第 45 回日本産科婦人科内視鏡学会 において発表した。

\section{参考文献}

1）謝 宗安：手術とガス塞栓、呼吸、2003；22：570574.

2 ）中村教人他：ラテックスアレルギー患者の麻醉経験、 麻酔、 $2000 ; 49: 777-781$.

3 ）西松欣也、釷宮豊城：手術用手袋に関する諸問題一ב ーンスターチパウダーを中心に一、臨床麻醉、2000；
$24: 57-63$.

4 ) Beezhold D、Beck WC. : Surgical glove powders bind latex antigens、Arch.Surg. $1992 ; 127: 1354$ 1357.

5 ) Gary M Liss et al : Latex allergy: epidemiological study of 1351 hospital workers、 Occup and Environ Med. 1997 ; $54: 335-342$.

6 ) Bousquet J et al : Natural rubber latex allergy among health care workers : a systematic review of the evidence、J Allergy Clin Immunol、 2006 ; 118 : 447454.

7 ) H Alenius、K Turjanmaa、T Palpsuo: Natural rubber latex allergy、Occup Environ Med、2002; $59: 419-424$.

8) Minako Sasaki, Katsuya Kanda : Glove Selection as Personal Protective Equipment and Occupational Dematitis among Japanese Midwives、 J.Occup Health、 $2006 ; 48: 35-43$.

9 ) 赤澤晃：ラテックス・フルーツ症候群、綜合臨床、 $2007 ; 56: 1852-1855$.

10）尾藤利憲、堀川達弥：ラテックスアレルギーとOAS、 皮膚アレルギーフロンティア、2007； 5 : 157-161.

11) K Turjanmaa et al、Allergy to latex gloves:unusual complication during delivery, BMJ $1988 ; 297$ : 1029.

12）富高晶子、松永佳世子：内科医に関連した皮虐科最新 疾患情報 ラッテクスアレルギー、診断と治療、 $2002 ; 90 ： 1537-1542$

13）松永佳世子、矢上晶子：ラテックスアレルギーの治療 および予防対策、皮䖉アレルギーフロンティア、 2004 ; 2 : 149-153 